\title{
GRAIN PRODUCTION, FATTY ACID AND OIL PROFILE FROM SUNFLOWER CULTIVARS RECEIVING DIFFERENT BORON DOSES
}

\author{
PRODUÇÃO DE GRÃOS, PERFIL DE ÓLEO E ÁCIDOS GRAXOS EM CULTIVARES \\ DE GIRASSOL SUBMETIDOS A DIFERENTES DOSES DE BORO
}

\section{Luiziene Soares ALVES ${ }^{1}$; Larissa Gasparelo MORAIS ${ }^{2}$; Munir MAUAD ${ }^{3}$; Diego de Mello Conde de BRITO ${ }^{4}$; André Marques dos SANTOS ${ }^{4 *}$; Rosane Nora CASTRO ${ }^{5}$; Sonia Regina de $\mathrm{SOUZA}^{4}$ (in memoriam).}

1. Doutora em Química, Universidade Federal Rural do Rio de Janeiro (UFRRJ), Seropédica, RJ, Brasil. luiziene@gmail.com. 2. Estudante de Engenharia Química, Universidade Federal Rural do Rio de Janeiro (UFRRJ), Seropédica, RJ, Brasil; 3. Professor na Faculdade de Ciências Agrárias, Universidade Federal da Grande Dourados (UFGD), Dourados, MS, Brasil; 4. Professor (a) do Departamento de Bioquímica, Universidade Federal Rural do Rio de Janeiro (UFRRJ), Seropédica, RJ, Brasil. *amarques@ufrrj.br; amarques.ufrrj@gmail.com. 5; Professora do Departamento de Química Orgânica, Universidade Federal Rural do Rio de Janeiro (UFRRJ), Seropédica, RJ, Brasil.

\begin{abstract}
Among the main factors that affect the productivity of crops is deficiency of nutrients. Boron (B) is an essential micronutrient for plants, and sunflower is one of the most sensitive plants to deficiency of the element. Its inadequate supply can impair sunflower plants' metabolism and grain and oil yield. The objective of this study was to assess the effect of different boron doses on the production of sunflower grains and the content and quality of the oil obtained from them. The experimental design was randomized blocks in a factorial scheme with three cultivars (Helio251, BRS323, BRS324) and four B doses $\left(0,2.5,5.0,8.0 \mathrm{~kg} \mathrm{ha}^{-1}\right)$. Two harvests were performed, the first in the R5 reproductive stage and the second at the end of the R9 cycle. In both cases, the levels of B in the capitulum were measured. At the end of the cycle, the grain yield, crude protein and oil content in the grains and fatty acid profile were analyzed. The cultivars responded differently to the treatments with B. The boron fertilization influenced the grain yield and oil content, but was not correlated with the profile of the majority unsaturated fatty acids and crude protein in the grains. Variations were observed in the fatty acid profile between the cultivars, an important aspect that needs to be evaluated according to the purpose of the production. In soil with lower availability of B, cultivar BRS323 was most efficient in B uptake, grain yield and oil content and quality.
\end{abstract}

KEYWORDS: Helianthus annuus L. Linoleic acid. Oil content. Crude protein.

\section{INTRODUCTION}

Sunflower is an important source of oil for the food industry because of its good quality, in particular the high level of unsaturated fatty acids and high concentration of vitamin E (BASHIR, 2015). The productivity of plants in general can be affected by the availability of nutrients, which influence their growth and development, and consequently crop yield. Among the micronutrients required by plants, boron (B) is particularly important for sunflower, since it needs higher quantities than most other crops. Boron is involved in various metabolic processes, such as structural integrity of the cell wall (POWER; WOODS, 1997), cell division, translocation of sugars, synthesis of proteins (LANDI et al., 2012), photosynthesis (VARSHNEY; FARIDUDDIN; YUSUF, 2015), nitrogen metabolism (CERVILLA et al., 2009), and pollen viability (KRUDNAK; WONPRASAID; MACHIKOWA, 2013), among others. Various researchers have demonstrated the effect of applying $\mathrm{B}$ on determined sunflower cultivars. Alves et al. (2017), when analyzing different sunflower cultivars with and without boron fertilization, found that the plants supplied with the micronutrient produced more grains and oil. Further according to them, the supply of boron in conditions of low nitrogen supply was fundamental to assure good grain and oil yields of one of the cultivars. Mehmood et al. (2018) also observed the influence of boron on the levels of oil and protein in the grains, which were higher than in the control plants when the micronutrient was applied. Shekhawat and Shivay (2008) reported that the application of boron improved the oil quality, by increasing the quantity of unsaturated and reducing the saturated fatty acids.

Despite the benefits that applying B can bring, an excess of the element can cause nutritional disturbances, thus impairing essential processes for plant development. Therefore, studies to determine the best doses of $\mathrm{B}$, the timing of application, the 
influence on different cultivars and the effects on productivity are necessary to enhance the cultivation of sunflower. The objective of this work was to assess the effects of applying different rates of B on the productive characteristics, oil content and quality of different sunflower cultivars.

\section{MATERIAL AND METHODS}

The experiment was conducted in the municipality of Dourados, Mato Grosso do Sul, Brazil, located at geographic coordinates $54^{\circ} 56^{\prime} \mathrm{W}$ and $22^{\circ} 12^{\prime} \mathrm{S}$ and elevation of $452 \mathrm{~m}$. The climate according to the Köppen classification is Cwa, characterized as humid mesothermal with rainy summers.

The soil in the experimental area is classified as a very clayey Dystroferric Red Latosol (EMBRAPA, 2013), with the following composition in the top $20 \mathrm{~cm}$ layer: $\mathrm{OM}: 30.0 \mathrm{~g} \mathrm{dm}^{-3} ; \mathrm{pH}_{(\mathrm{CaCl})}$ : 5.6; $\mathrm{P}_{(\text {resin) }}: 35.0 \mathrm{mg} \mathrm{dm}{ }^{-3} ; \mathrm{K}^{+}, \mathrm{Ca}^{2+}$ and $\mathrm{Mg}^{2+}: 3.3,67$ and $22 \mathrm{mmol} \mathrm{dm}{ }^{-3}$, respectively; $\mathrm{S}_{-S_{4}}^{-2}: 3.0 \mathrm{mg}$ $\mathrm{dm}^{-3}$; B $0.28 \mathrm{mg} \mathrm{dm}^{-3}$ and $\mathrm{V}=73 \%$. The granulometric analysis of this layer revealed values of 644,203 and $152 \mathrm{~g} \mathrm{~kg}^{-1}$ of clay, silt and sand, respectively.

The experimental design was randomized blocks in a $3 \times 4$ factorial scheme, consisting of three sunflower cultivars (BRS323, BRS324 and Helio251) and four B doses (0, 2.5, 5 and $8.0 \mathrm{~kg} \mathrm{ha}$ ${ }^{1}$ ), with four repetitions, for a total of 48 plots. Each plot was composed of six rows with length of $6 \mathrm{~m}$, with spacing of $0.7 \mathrm{~m}$ between rows and $0.30 \mathrm{~m}$ between plants in the row. For useful area, the plants in the two central rows were used, also with elimination of the last $1 \mathrm{~m}$ of each row.

The grains were sown manually on January 21, 2016. Ten days after emergence (DAE), when the plants were in the V2 stage, they were culled to adjust the population to 48,000 plants $\mathrm{ha}^{-1}$. At the time of sowing, all the plots received $300 \mathrm{~kg}$ of 820-20 fertilizer $\mathrm{N}, \mathrm{P}_{2} \mathrm{O}_{5}$ and $\mathrm{K}_{2} \mathrm{O}$ in the furrow. Twenty-five days after emergence, top dressing of $26 \mathrm{~kg}$ of $\mathrm{N} \mathrm{ha}^{-1}$ was applied using urea as the source.

The boron doses were applied with a backmounted sprayer under pressure $\left(\mathrm{CO}_{2}\right)$, equipped with a 3 meters bar and six XR Teejet 110.02 VS nozzles, spaced 0.50 apart. The volume of liquid applied was $80 \mathrm{~L} \mathrm{ha}^{-1}$. Manual weeding was performed 15 and 30 DAE.

Two harvests were performed, one in the R5 reproductive stage and the other at the end of the cycle, during grains maturation in stage R9. In the first case, only the concentration of $\mathrm{B}$ in the capitulum was evaluated, while in the second case the concentration of B in the capitulum and grains, grain yield, levels of protein and oil in the grains, and fatty acid profile were assessed. The levels of B in the capitulum and grains were determined by the colorimetric method with the reagent azomethine-H (MALAVOLTA; VITTI; OLIVEIRA, 1997).

The concentration of crude protein was determined by the Kjeldahl method, where the nitrogen levels obtained were multiplied by the correction factor 6.25 (ALVES et al., 2012).

The oil was extracted in a Soxhlet extractor for four hours with the solvent hexane. After evaporation of the solvent, the oil samples were weighed to determine the yield. The fatty acid profile was characterized by gas chromatography combined with mass spectrometry (CG-MS), using a Shimadzu CGMS-QP2010 Plus system and Agilent HP-5 column ( $30 \mathrm{~m} \times 0.25 \mathrm{~mm} \times 0.25 \mu \mathrm{m})$. The fatty acids were identified by comparison against mass spectra in the NIST 6.2 and NIST 1.2 libraries and the FAME Mix C4-C24 standard (Sigma-Aldrich).

The data were checked for normal distribution by the Shapiro-Wilk test and homoscedasticity of variances by the Breusch-Pagan test, utilizing the lmtest package. Then the results were submitted to analysis of variance using the Ftest, and when there was a significant effect of the quantitative variables, a quadratic regression model was fitted. In cases of significant interaction between cultivar and B dose, the Tukey test was applied to compare the means, using the ExpDes.pt package (FERREIRA et al., 2013). All the analyses were performed with the R 3.3.0 software.

\section{RESULTS AND DISCUSSION}

\section{Analysis of Boron}

In the first harvest sampling, at stage R5, the Helio251 cultivar absorbed more B in the presence of lower availability of the nutrient $\left(0\right.$ and $2.5 \mathrm{~kg}^{-}{ }^{-}$ $\left.{ }^{1}\right)$ than the other two cultivars (Table 1). This greater remobilization of the nutrient can be related to the greater demand of this cultivar for the element B. The presence of $\mathrm{B}$ in the plants grown without application of that micronutrient can be explained by the presence of a small amount in the soil. Thus, under these conditions, high-affinity transporters regulated in response to $\mathrm{B}$ availability in the environment are activated (MIWA; FUJIWARA, 2010). In the treatment with the highest $B$ dose $(8$ $\left.\mathrm{kg} \mathrm{ha}^{-1}\right)$, the quantity of $\mathrm{B}$ in the capitulum was the same for all the cultivars in the first harvest (Table $1)$. 
In the second harvest, after complete maturation of the grains, the levels of $\mathrm{B}$ in the capitulum and grains increased in all the cultivars (Table 1), indicating the nutrient was remobilized due to its participation in floral bud formation and pollen tube development (JAIN et al., 2014). It is known that $\mathrm{B}$ is transported through the xylem vessels to places with greater water loss. Plant species differ markedly regarding the mobility of $\mathrm{B}$, and can be classified into species in which the micronutrient's redistribution is restricted and species in which B is highly mobile (BROWN; SHELP, 1997).

Table 1. Level of B in the capitulum in the first harvest (stage R5) and in the capitulum and grains in the second harvest (end of the cycle) of sunflower cultivars BRS323, BRS324 and Helio251, cultivated with different B doses, at the experimental farm of Universidade Federal da Grande Dourados.

\begin{tabular}{|c|c|c|c|c|c|c|}
\hline \multicolumn{7}{|c|}{ B content ( $\left.\mathrm{mg} \mathrm{kg}^{-1}\right)$} \\
\hline \multirow{2}{*}{$\begin{array}{l}\text { Boron } \\
\text { doses }\end{array}$} & \multicolumn{3}{|c|}{ Capitulum $1^{\text {st }}$ harvest (R5) } & \multicolumn{3}{|c|}{ Capitulum $2^{\text {nd }}$ harvest (R9) } \\
\hline & BRS323 & BRS324 & Helio251 & BRS323 & BRS324 & Helio251 \\
\hline I & $13.28 \mathrm{~B}$ & $14.48 \mathrm{~B}$ & $19.52 \mathrm{~A}$ & $38.10 \mathrm{~B}$ & $17.34 \mathrm{C}$ & $47.95 \mathrm{~A}$ \\
\hline II & $14.25 \mathrm{~B}$ & $13.51 \mathrm{~B}$ & $17.70 \mathrm{~A}$ & $37.57 \mathrm{~A}$ & $38.18 \mathrm{~A}$ & $42.64 \mathrm{~A}$ \\
\hline III & $16.57 \mathrm{~A}$ & $13.12 \mathrm{~B}$ & $17.46 \mathrm{~A}$ & $52.93 \mathrm{~A}$ & $22.20 \mathrm{~B}$ & $52.50 \mathrm{~A}$ \\
\hline IV & $14.31 \mathrm{~A}$ & $14.87 \mathrm{~A}$ & $15.67 \mathrm{~A}$ & $23.55 \mathrm{~B}$ & $37.06 \mathrm{~A}$ & $22.83 \mathrm{~B}$ \\
\hline
\end{tabular}

\begin{tabular}{|c|c|c|c|c|c|c|}
\hline \multirow{2}{*}{$\begin{array}{l}\text { Boron } \\
\text { doses }\end{array}$} & \multicolumn{3}{|c|}{ Grain $2^{\text {nd }}$ harvest } & \multicolumn{3}{|c|}{ Capitulum + Grain ( $2^{\text {nd }}$ harvest) } \\
\hline & BRS323 & BRS324 & Helio251 & BRS323 & BRS324 & Helio251 \\
\hline I & $32.49 \mathrm{~A}$ & $22.12 \mathrm{~B}$ & $21.61 \mathrm{~B}$ & $70.59 \mathrm{~A}$ & $39.46 \mathrm{~B}$ & $69.56 \mathrm{~A}$ \\
\hline II & $25.29 \mathrm{~A}$ & $21.16 \mathrm{~B}$ & $20.45 \mathrm{~B}$ & $62.86 \mathrm{~A}$ & $59.34 \mathrm{~A}$ & $63.09 \mathrm{~A}$ \\
\hline III & $21.67 \mathrm{~B}$ & $24.31 \mathrm{~A}$ & $16.50 \mathrm{C}$ & $74.60 \mathrm{~A}$ & $46.50 \mathrm{~B}$ & $69.00 \mathrm{~A}$ \\
\hline IV & $24.85 \mathrm{~A}$ & $19.08 \mathrm{~B}$ & $26.67 \mathrm{~A}$ & $48.39 \mathrm{~B}$ & $56.14 \mathrm{~A}$ & $49.5 \mathrm{AB}$ \\
\hline
\end{tabular}

At the end of the cycle, the application of 5 $\mathrm{kg} \mathrm{ha}^{-1}$ of $\mathrm{B}$ resulted in the highest levels of $\mathrm{B}$ in the tissues of cultivar BRS324 (Figure 1A), but this did not result in higher grain yield (Figure 2B). For Helio251, the treatment with the highest dose resulted in a higher level of the micronutrient in the capitulum + grain (Figure 1A), and thus higher grain yield (Figure 2B).

The cultivar BRS323 remobilized more B to the grains under conditions of low availability of the element (Figure 1A), so it was considered more efficient that the other two cultivars. This fact might have contributed to the maintenance of high productivity of this cultivar in the absence of $\mathrm{B}$ fertilization (Figure 1B). In this case, the uptake of $B$ probably occurred through non-selective membrane channels or high-affinity transporters, both activated under conditions of low B availability (PRINCI et al., 2016).

Cultivar Helio251 was the most sensitive to variations of $\mathrm{B}$ availability, because its productivity was greater with the highest $\mathrm{B}$ doses $\left(5\right.$ and $8 \mathrm{~kg}^{-}$ $\left.{ }^{1}\right)$ than with the other doses (Figure 1B). Khan et al. (2015) also found a beneficial effect of applying B on the grain production of sunflower hybrids (Patron 551 and S-278).
Cultivar BRS324, although its grain yield did not increase with $\mathrm{B}$ doses, had the highest oil yields in the treatment with the largest B dose $(8 \mathrm{~kg}$ $\mathrm{ha}^{-1}$ ) and similar results between low and high doses, showing its adaptation to both growing conditions (Figure 1D). (TAHIR; ASHRAF; IBRAHIM, 2013) observed higher oil content in sunflower hybrid Hysun-33 when applying $8 \mathrm{~kg} \mathrm{ha}^{-1}$ of $\mathrm{B}$ during the floral bud initiation stage. Here, the treatments did not affect the oil production in the cultivar BRS323, but Helio251 had peak oil production with the dose of $5 \mathrm{~kg}$, followed by decline at the dose of $8 \mathrm{~kg} \mathrm{ha}^{-1}$ (Figure 1D).

Among the cultivars, Helio251 had highest oil production with the $\mathrm{B}$ dose of $5 \mathrm{~kg} \mathrm{ha}^{-1}$, while BRS324 had the highest production at doses of 2.5 and $8 \mathrm{~kg} \mathrm{ha}^{-1}$.

The application of B caused in increase in the number of grains produced by cultivar Helio251 (Figure 1C), demonstrating its greater sensitivity to the absence of the micronutrient. As demonstrated by (PATTANAYAK et al., 2017), B is related to the formation of the pollen tube during the flowering period. Likewise, in our study the greater number of grains in cultivar Helio251 might be related to the higher fecundation during flowering promoted by the boron fertilization. Mekki (2015) also reported a 
larger number of grains produced by sunflower with

boron application.
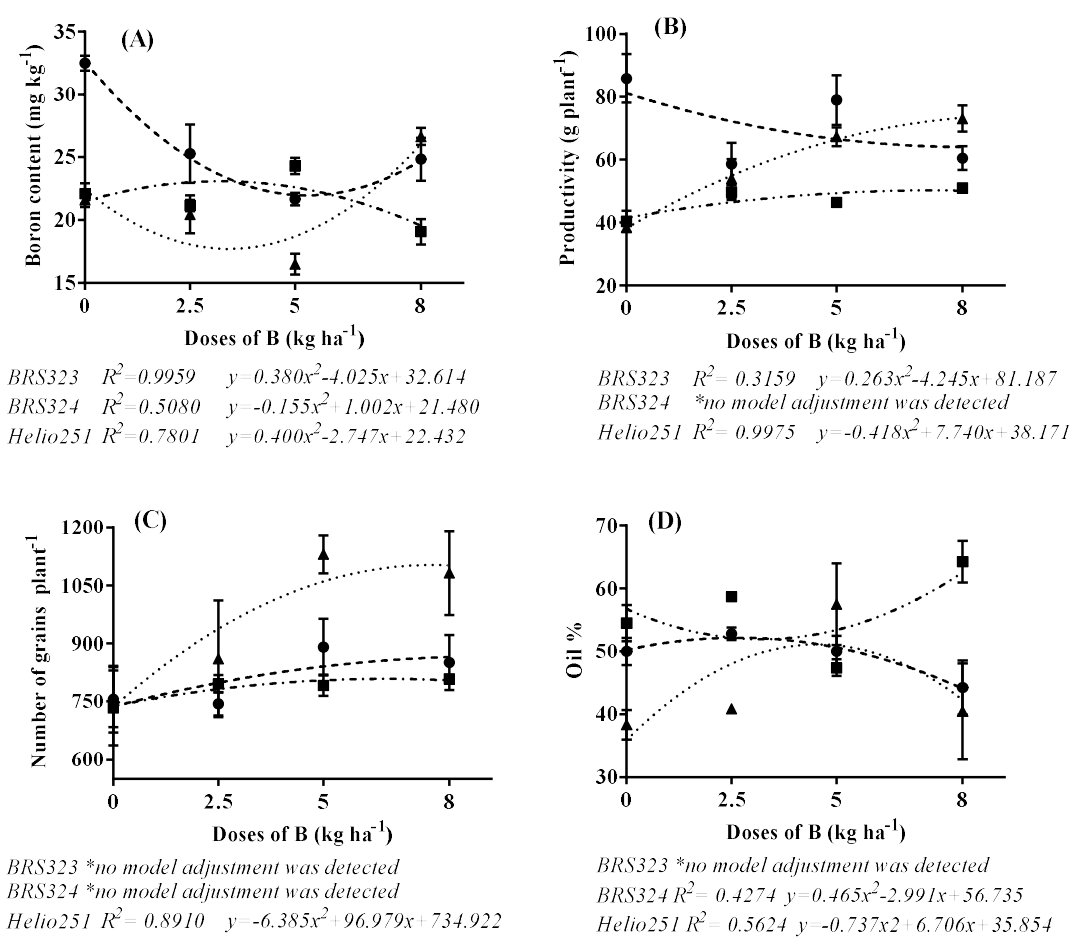

BRS323

A. Helio251

Figure 1. Regression curves of the behavior of sunflower cultivars Helio251, BRS323 and BRS324 in function of B doses applied in the field $\left(0,2.5,5.0\right.$ and $\left.8.0 \mathrm{~kg} \mathrm{ha}^{-1}\right)$.

(A) Boron levels in the capitulum + grains $\left(\mathrm{mg} \mathrm{kg}^{-1}\right)$. (B) Grain productivity $\left(\mathrm{g}\right.$ plant $\left.{ }^{-1}\right)$. (C) Number of grains produced per plant. (D) Oil concentration (\%).
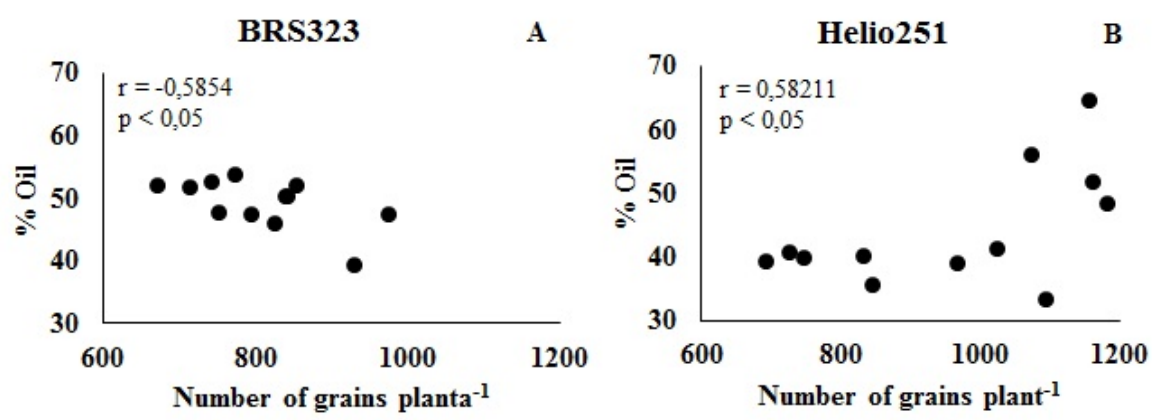

Figure 2. Correlation between oil concentrations (\%) and number of grains produced by sunflower cultivars BRS323 and Helio251.

The correlation between quantity of grains produced and oil concentrations was negative for cultivar BRS323 (Figure 2 A). A dilution effect was observed, since more grains were produced but the oil yield per grain was lower. On the other hand, for Helio251 this correlation was positive (Figure 2, B), because the content of oil per grain rose with the increase in the number of grains. Alves et al. (2017) found a positive correlation between grain production and oil production in different sunflower cultivars.

\section{Crude protein content in the grains}

The levels of crude protein in the grains were not altered by the boron fertilization, but a genotypic difference was observed for that character. Cultivar BRS323 had the highest levels of protein (Table 2). These results are in opposition to those found by (MEHMOOD et al., 2018), who observed a higher protein content in sunflower hybrids (Hysun-33 and DK-4040) when applying B and lower content in the control plants. These differences between the results add further evidence of genotypic particularities. 
Table 2. Percentage of crude protein in the grains of different sunflower cultivars (BRS323, BRS324 and Helio251) submitted to different doses of B.

\begin{tabular}{llll}
\hline Boron & \multicolumn{2}{l}{ Crude protein (\%) } & Helio251 \\
\cline { 2 - 4 } Doses & BRS323 & BRS324 & 20.2 \\
I & 21.5 & 19.2 & 16.6 \\
II & 19.8 & 15.0 & 17.0 \\
III & 23.3 & 16.9 & 18.6 \\
IV & 20.8 & 17.2 & $18.1 \mathrm{~B}$ \\
\hline Means & $21.4 \mathrm{~A}$ & $17.1 \mathrm{~B}$ & \\
\hline
\end{tabular}

*I: $0 \mathrm{~kg} \mathrm{ha}^{-1} ;$ II: $2.5 \mathrm{~kg} \mathrm{ha}^{-1} ;$ III: $5 \mathrm{~kg} \mathrm{ha}^{-1} ; \mathrm{IV}: 8 \mathrm{~kg} \mathrm{ha}^{-1}$. Averages followed by the same capital letters in line do not differ by Tukey's test at the $5 \%$ significance level.

\section{Oil quality}

The B doses did not influence the proportions of linoleic and oleic acids in the grains of the cultivars evaluated, with the only differences again being genotypic. Among the three, Helio251 produced the most linoleic acid and the least oleic acid, while BRS323 produced the most oleic acid and least linoleic acid (Table 3). Monounsaturated acids, such as oleic, are attractive to the food industry because they undergo less pronounced oxidative alterations than polyunsaturated acids, such as linoleic, during processing (MEKKI, 2015).

Table 3. Concentrations (\%) of linoleic and oleic acids in the oil of sunflower cultivars BRS 323, BRS 324 and Helio251 cultivated with different B doses $\left(0,2.5,5.0\right.$ and $\left.8.0 \mathrm{~kg} \mathrm{ha}^{-1}\right)$, applied at sowing.

\begin{tabular}{|c|c|c|c|c|c|c|}
\hline \multirow{2}{*}{$\begin{array}{l}\text { Boron } \\
\text { Doses }\end{array}$} & \multicolumn{3}{|c|}{ Linoleic (C18:2) } & \multicolumn{3}{|c|}{ Oleic (C18:1) } \\
\hline & BRS323 & BRS324 & Helio251 & BRS323 & BRS324 & Helio251 \\
\hline $\mathbf{I}$ & 39.48 & 40.34 & 44.17 & 42.53 & 41.54 & 34.80 \\
\hline II & 40.19 & 40.40 & 46.15 & 42.33 & 39.27 & 32.82 \\
\hline III & 38.24 & 40.79 & 46.56 & 42.34 & 39.13 & 33.00 \\
\hline IV & 37.95 & 41.34 & 43.93 & 44.65 & 39.17 & 35.64 \\
\hline Means & 38.97 C & 40.72 B & $40.20 \mathrm{~A}$ & $42.96 \mathrm{~A}$ & 39.78 B & 34.07 C \\
\hline
\end{tabular}

*I: $0 \mathrm{~kg} \mathrm{ha}^{-1}$; II: $2.5 \mathrm{~kg} \mathrm{ha}^{-1}$; III: $5 \mathrm{~kg} \mathrm{ha}^{-1}$; IV: $8 \mathrm{~kg} \mathrm{ha}^{-1}$. Averages followed by the same capital letters in line do not differ by Tukey's test at the $5 \%$ significance level.

Cultivar BRS324 presented medium levels of both acids (linoleic and oleic). Differences were observed in the fatty acid profile of each cultivar (Figure 3). Dhillon, Sharma and Sharma (2017) did not observe an influence of leaf application of boron on the fatty acid profile of sunflower. In turn, Mekki (2015) detected that B influenced the profile of palmitic, stearic, oleic and linoleic acids in two sunflower cultivars (Sakha-53 and Giza-102) submitted to leaf application of the nutrient. Our results corroborate those earlier findings, reinforcing the idea that the response to $\mathrm{B}$ can be different regarding the fatty acid profiles found, a trait mainly governed by the genotypic characteristics of the cultivar.

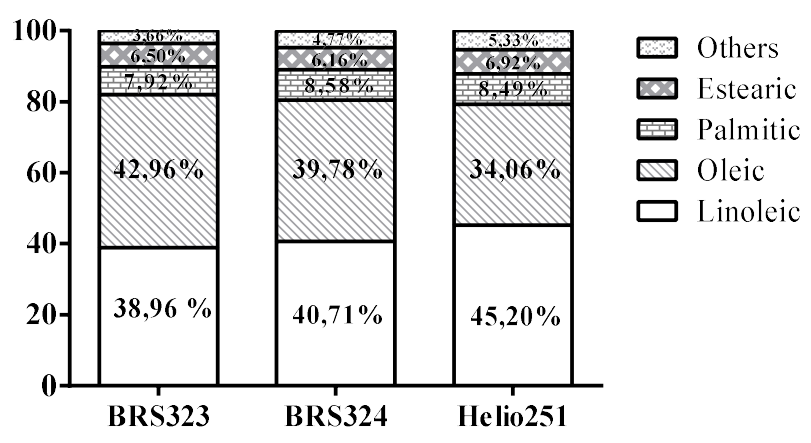

Figure 3. Effect of genotypic traits on the profile of fatty acids present in the oil of different sunflower cultivars (BRS323, BRS324 and Helio251). 
With respect to the saturated fatty acids, the concentrations of palmitic and stearic acids fluctuated among the doses and cultivars (Table 4). Although palmitic and stearic acids are precursors for the synthesis of unsaturated fatty acids, oleic and linoleic acids did not present oscillations in their profiles, demonstrating that these acids were not influenced by the doses of B applied.

Although cultivar BRS324 presented the highest level of palmitic acid when the B dose of 5 $\mathrm{kg}$ was applied (Table 4), this dose should not be recommended for production of oil for human consumption, which should give preference for oils with higher concentrations of unsaturated fatty acids. The same comment applies to Helio251 in relation to the content of stearic acid, which was highest in the absence of $\mathrm{B}$, followed by a decline in the treatment for best oil yield ( $5 \mathrm{~kg} \mathrm{ha}^{-1}$; Table 4$)$.

Table 4. Concentrations (\%) of palmitic and stearic acids in the oil of sunflower cultivars BRS 323, BRS 324 and Helio251 cultivated with different $B$ doses $\left(0,2.5,5.0\right.$ and $\left.8.0 \mathrm{~kg} \mathrm{ha}^{-1}\right)$, applied at sowing.

\begin{tabular}{|c|c|c|c|c|c|c|}
\hline \multirow{2}{*}{ Dose } & \multicolumn{3}{|c|}{ Palmitic (C16:0) } & \multicolumn{3}{|c|}{ Stearic (C18:0) } \\
\hline & BRS323 & BRS324 & Helio251 & BRS323 & BRS324 & Helio251 \\
\hline $\mathbf{I}$ & $7.69 \mathrm{~B}$ & $8.29 \mathrm{~A}$ & $8.49 \mathrm{~A}$ & $6.23 \mathrm{~B}$ & $6.35 \mathrm{~B}$ & $7.33 \mathrm{~A}$ \\
\hline II & $8.05 \mathrm{~B}$ & $8.31 \mathrm{AB}$ & $8.75 \mathrm{~A}$ & $6.84 \mathrm{~A}$ & $5.92 \mathrm{C}$ & $6.39 \mathrm{~B}$ \\
\hline III & $7.67 \mathrm{C}$ & $9.14 \mathrm{~A}$ & $8.38 \mathrm{~B}$ & $6.31 \mathrm{AB}$ & $6.14 \mathrm{~B}$ & $6.64 \mathrm{~A}$ \\
\hline IV & $8.26 \mathrm{~A}$ & $8.60 \mathrm{~A}$ & $8.34 \mathrm{~A}$ & $6.65 \mathrm{~A}$ & $6.25 \mathrm{AB}$ & $6.32 \mathrm{~B}$ \\
\hline
\end{tabular}

*I: $0 \mathrm{~kg} \mathrm{ha}^{-1}$; II: $2.5 \mathrm{~kg} \mathrm{ha}^{-1}$; III: $5 \mathrm{~kg} \mathrm{ha}^{-1}$; IV: $8 \mathrm{~kg} \mathrm{ha}^{-1}$. Averages followed by the same capital letters in lines do not differ by Tukey's test at the $5 \%$ significance level.

Altogether, the data indicate that cultivar BRS323 is most efficient in absorbing $\mathrm{B}$ and productivity of grains in soils with low availability of this element (dose of $0 \mathrm{~kg} \mathrm{ha}^{-1}$ ). When compared with the other cultivars, BRS323 presented the highest levels of crude protein and oleic acid. On the other hand, cultivar Helio251 presented the highest concentrations of linoleic acid and best grain yield and oil content in the treatment with $5 \mathrm{~kg} \mathrm{ha}^{-1}$. Finally, BRS324, although its productivity was not influenced by B application, showed a higher content of oil in the grains when this micronutrient was applied.

\section{CONCLUSIONS}

The results show the importance of $B$ for grain productivity and oil content of sunflower.
However, the three cultivars reacted differently to application of the micronutrient, so it is necessary to verify the best dose for each cultivar.

In relation to fatty acid profile and crude protein content in the grains, no influence was observed of boron application on the oil quality, adding evidence to the idea that genotypic traits are the determinants, elucidating the agronomic potential of each cultivar evaluated.

\section{ACKNOWLEDGEMENTS}

The authors are grateful to Petrobras Biocombustível (Petro Bio Girassol) and Coordenação de Aperfeiçoamento de Pessoal de Nível Superior - Brasil (CAPES) - Finance Code 001.

RESUMO: Dentre os principais fatores que afetam a produtividade das culturas está a deficiência de nutrientes. O Boro (B) é um micronutriente essencial para plantas, e o girassol é uma das mais sensíveis à deficiência desse elemento. Seu fornecimento inadequado pode prejudicar o metabolismo, a produção de óleo e grãos das plantas de girassol. O objetivo deste estudo foi avaliar o efeito de diferentes doses de boro na produção de grãos, conteúdo a qualidade do óleo de girassol. O experimento foi conduzido em delineamento de blocos ao acaso em esquema fatorial com três cultivares (Helio251, BRS323, BRS324) e quatro doses de B (0; 2,$\left.5 ; 5,0 ; 8,0 \mathrm{~kg} \mathrm{ha}^{-1}\right)$. Foram realizadas duas coletas, a primeira na fase reprodutiva $\mathrm{R} 5$ e a segunda no final do ciclo R9. Em ambos os casos, os níveis de B no capítulo foram medidos. No final do ciclo, foram analisados a produção de grãos, teor de proteína bruta e óleo nos grãos e perfil de ácidos graxos. Os cultivares responderam diferentemente aos tratamentos com B. A adubação com boro influenciou o rendimento de grãos e teor de óleo, mas não se correlacionou com o perfil da maioria dos ácidos graxos insaturados e da proteína bruta nos grãos. Foram observadas variações no perfil de ácidos graxos entre cultivares, um aspecto importante que precisa ser 
avaliado de acordo com a finalidade da produção. No solo com menor disponibilidade de B, o cultivar BRS323 foi mais eficiente na absorção de B, rendimento de grãos, teor e qualidade de óleo.

PALAVRAS-CHAVE: Helianthus annuus L. Ácido linoleico. Conteúdo de óleo. Proteína bruta.

\section{REFERENCES}

ALVES, F. V.; JUNIOR, A. S.; SANTANA, D. G.; dos SANTOS, C. M. Composição química e qualidade fisiológica de sementes de girassol de plantas submetidas à competição intraespecífica. Revista Brasileira de Sementes, v. 34, n. 3, p. 457-46, 2012. https://doi.org/10.1590/S0101-31222012000300013

ALVES, L. S.; STARK, E. M. L. M.; ZONTA, E.; FERNANDES, M. S.; SANTOS, A. M.; SOUZA, S. R. Different nitrogen and boron levels influence the grain production and oil content of a sunflower cultivar. Acta Scientiarum. Agronomy, v. 39, n. 1, p. 59-66, 2017. http://dx.doi.org/10.4025/actasciagron.v39i1.30941

BASHIR, T. Chemistry, Pharmacology and Ethnomedicinal Uses of Helianthus annuus (Sunflower): A Review. Pure and Applied Biology, v. 4, n. 2, p. 226-235, 2015.

BROWN, P. H.; SHELP, B. J. Boron mobility in plants. Plant and Soil, v. 193, n. 1-2, p. 85-101, 1997. https://oi.org/10.1023/A:1004211925160

CERVILLA, L. M.; BLASCO, B.; RÍOS, J. J.; ROSALES, M. A.; RUBIO-WILHELMI, M. M.; SÁNCHEZ-RODRÍGUEZ, E.; RUIZ, J. M. Response of nitrogen metabolism to boron toxicity in tomato plants. Plant Biology (Stuttgart), v. 11, n. 5, p. 671-7, 2009. https://doi.org/10.1111/j.1438-

8677.2008.00167.x

DHILLON, B. S.; SHARMA, P. K.; SHARMA, S. Oil yield and fatty acid profile of staggered sown Spring sunflower (Helianthus annuus L.) in response to foliar application of boron and tiba. Applied Biological Research, v. 19, n. 2, p. 156-163, 2017. https://doi.org/10.5958/0974-4517.2017.00022.2

Empresa Brasileira de Pesquisa Agropecuária - EMBRAPA. Sistema brasileiro de classificação de solos. 3.ed. Brasília, Brasil, 2013.

FERREIRA, E. B.; CAVALCANTI, P. P.; NOGUEIRA, D. A. ExpDes.pt: Experimental Designs pacakge (Portuguese). R package version 1.1.2., 2013.

JAIN, R.; PATANGRAV, A. J.; RATHORE, A. K.; NAYAK, T. Boron: An important element for agricultura productivity. Asian Journal of Multidisciplinary Studies, v. 2, n. 2, p.35-41, 2014.

KHAN, I.; ANJUM, S. A.; QARDRI, R. W. K.; ALI, M.; CHATTHA, M. U.; ASIF, M. Boosting Achene Yield and Yield Related Traits of Sunflower Hybrids through Boron Application Strategies. American Journal of Plant Sciences, v. 6, p. 1752-1759, 2015. https://doi.org/10.4236/ajps.2015.611175

KRUDNAK, A.; WONPRASAID, S.; MACHIKOWA, T. Boron affects pollen viability and seed set in sunflowers. African Journal of Agricultural Research, v. 8, n. 2, p. 162-166, 2013.

https://doi.org/10.5897/AJAR12.1471

LANDI, M.; DEGL'INNOCENTI, E.; PARDOSSI, A.; GUIDI, L. Antioxidant and photosynthetic responses in plants under boron toxicity: A Review. American Journal of Agricultural and Biological Sciences, v. 7, n. 3 , p. 255-270, 2012. https://doi.org/10.3844/ajabssp.2012.255.270

MALAVOLTA, E.; VITTI, G. C.; OLIVEIRA, S. A. Avaliação do estado nutricional de plantas: princípios e aplicações. Potafós, Piracicaba, SP, Brasil, 1997. 
MEHMOOD, A.; SALEEM, M. F.; TAHIR, M.; SARWAR, M. A.; ABBAS, T.; ZOHAIB, A.; ABBAS, H. T. Sunflower (Helianthus annuus L) Growth, Yield and Oil Quality Response to Combined Application of Nitrogen and Boron. Pakistan Journal of Agricultural Research, v. 31, n. 1, p. 86-97, 2018. nitrogen and boron. Pakistan Journal of Agricultural Research, 31(1): 86-97.

http://dx.doi.org/10.17582/journal.pjar/2018/31.1.86.97

MEKKI, B. E. Effect of Boron Foliar Application on Yield and Quality of Some Sunflower (Helianthus annuus L.) Cultivars. Journal of Agricultural Science and Technology B, v. 5, n. 5, p. 309-316, 2015. http://dx.doi.org/10.17265/2161-6264/2015.05.002

MIWA, K.; FUJIWARA, T. Boron transport in plants: co-ordinated regulation of transporters. Annals of Botany, v. 105, n. 7, p. 1103-1108. 2010. https://doi.org/10.1093/aob/mcq044

PATTANAYAK, S.; BEHERA, A. K.; DAS, P.; NAYAK, M. R.; JENA, S. N.; BEHERA, S. Performance of summer sunflower (Helianthus annuus L .) hybrids under different nutrient management practices in coastal Odisha. Journal of Applied and Natural Science, v. 9, n. 1, p. 435-440, 2017.

https://doi.org/10.31018/jans.v9i1.1209

POWER, P. P.; WOODS, W. G. The chemistry of boron and its speciation in plants. Plant and Soil, v. 193, n. 1-2, p. 1-13, 1997. https://doi.org/10.1023/A:1004231922434

PRINCI, M. P.; LUPINI, A.; ARANITI, F.; LONGO, C.; MAUCERI, A.; SUNSERI, F.; ABENAVOLI, M. R. Boron toxicity and tolerance in plants: recent advances and future perspectives. In: Parvaiz, A. (Ed.). Plant metal interaction: Emerging Remediation Techniques. Elsevier. Amsterdam, 2016.

https://doi.org/10.1016/B978-0-12-803158-2.00005-9

SHEKHAWAT, K.; SHIVAY, Y. S. Effect of nitrogen sources, sulphur and boron levels on productivity, nutrient uptake and quality of sunflower (Helianthus annuus). Indian Journal of Agronomy, v. 53, n. 2, p. 129-134, 2008.

TAHIR, M.; ASHRAF, S.; IBRAHIM, M. Effect of Foliar Application of Boron on Yield and Quality of Sunflower (Helianthus annuus L.). Crop and Environment, v. 4, n. 1, p. 23-27, 2013.

VARSHNEY, P.; FARIDUDDIN, Q.; YUSUF, M. Boron induced modulation in growth, photosynthesis and antioxidant system in two varieties of Brassica juncea. International Journal of Advanced Research, v. 3, n. 10, p. 819-832, 2015. https://doi.org/10.1016/j.sjbs.2013.01.006 